\title{
CONTROL OF THE TECTONIC STRESS FIELD ON COAL AND GAS OUTBURST
}

\author{
GONG, W. ${ }^{*}-$ GUO, D. \\ College of Resources \& Safety Engineering, China University of Mining \& Technology \\ Beijing 100083, China \\ ${ }^{*}$ Corresponding author \\ e-mail: gwd1202@126.com
}

(Received 28 $8^{\text {th }}$ Apr 2018; accepted 31 $1^{\text {st }}$ Jul 2018)

\begin{abstract}
The comprehensive hypothesis of coal and gas outburst (CAGO), which considers that the in situ stress, gas pressure and content, and physical-mechanical properties of coal are the key factors in determining the occurrence of CAGO, is accepted by international scholars. Tectonic stress is the horizontal in situ stress that plays a leading role in the control of CAGO. To study the control of tectonic stress field on CAGO, the Pingdingshan eastern mining area is taken as a research area, and the evolution law of the regional tectonic stress field and the distribution characteristics of the modern tectonic stress field are analyzed. Combined with the characteristics of CAGO in this area, the effects of the tectonic stress field on the geological structure distribution, gas occurrence and tectonic coal development are discussed, and the effects of the tectonic stress field on CAGO are further studied. The results show that the evolution of the tectonic stress field forms the geological structure pattern of the Pingdingshan eastern mining area, leading to the differences in the distribution of gas occurrence in different areas of the mine area and resulting in a large area of tectonic coal development. The modern tectonic stress field exacerbates the pulverization and mylonitization of tectonic coal and influences the gas pressure and content through the coal reservoir permeability. The modern tectonic stress is the direct cause of CAGO, increasing the possibility and risk of CAGO.
\end{abstract}

Keywords: tectonic stress field, accident, gas occurrence, tectonic coal, fault

\section{Introduction}

Coal and gas outburst (CAGO) is one of the most serious disasters during the mining process in coal mines and is a complex geodynamic phenomenon caused by the collective effect of coal, gas and the surrounding rock (Aguado and Nicieza, 2007; Torano et al., 2012). Coal and gas outburst accidents not only damage mining equipment and roadways but also cause many work-related casualties (Beamish and Crossdale, 1998; Lama and Bodziony, 1998). China is the country with the most CAGO events. Thus far, there have been more than 15,000 CAGO accidents; from 2001 to 2012, there were 417 CAGO accidents in China, with 2,743 deaths. In 2004, a large CAGO accident occurred in the Daping coal mine in Zhengzhou, killing 148 people, injuring 32 people, and directly economic losses amounting to 39.357 million yuan. The huge pain was brought to the miners' family by the accident, moreover, the huge economic losses and casualties were brought to the society. The coal industry has become one of the most dangerous industries in the country. Although the technical input and policy guidance for CAGO management has been increased by the country has since 2012, the number of coal and gas outburst accidents has decreased significantly, but most people are still reluctant to engage in the coal industry. It can be seen that a very bad impact on the entire social environment has been caused by CAGO accidents, and a negative effect on China's international image has been also been generated. Meanwhile, a large amount of methane was poured out during the process of 
CAGO. Methane is a greenhouse gas, furthermore, the greenhouse effect of gas is 40 times that of $\mathrm{CO}_{2}$. Therefore, the serious greenhouse effect can be caused by CAGO. At present, the methane that normally flows out of coal mining is collectively drained and discharged after clean treatment, which has little impact on the ecological environment. However, the methane generated in CAGO is abnormally gushing, and a large amount of methane is often poured out in accidents. For instance, a total of $40000 \mathrm{~m}^{3}$ of methane was poured out in the largest CAGO accident in the Pingdingshan mining area. Every year, a very large amount of methane is poured out from outburst accidents, what's more, these gases have not been directly discharged through clean treatment. The serious greenhouse effect is caused by CAGO, and the balance of the natural ecological environment and the survival of human beings are seriously endangered. In recent years, the protection of the ecological environment has been increasingly valued by the Chinese government, reducing CAGO accidents is in line with national environmental protection requirements. In a word, the prevention and control of CAGO are not only beneficial to protecting and improving the ecological environment, but also beneficial to reducing casualties and property losses and improving the social environment.

Recognizing the mechanism of CAGO is the basis to preventing the occurrence of the accident. However, due to the fatal nature of CAGO, along with the large scale of coal and gas outbursts, a true repetitive simulation is difficult, so the precise mechanism of outburst is still unresolved. At present, the comprehensive theory of CAGO widely accepted by international researchers is that outburst is the result of the combined effect of factors such as the stress, gas, and physical and mechanical properties of coal (Zhang and Lowndes, 2010; Diamond and Schatzel, 1998; He et al., 2010). The coal body is broken and softened by the ground stress in the launch phase, which is more prone to instability. Furthermore, due to the long-term compression of the in situ stress, elastic energy potential is accumulated in the coal and rock mass, which is the energy source of outburst. In situ stress is mainly composed of tectonic stress and gravity stress; when the process of geological evolution is the same in a mining area, the lithology of the overlying strata is the same or similar, and the gravity stress generally linearly increases with the depth (Ding and Liang, 1985; Martin and Chandler, 1993; Sbar et al., 1979). However, tectonic stress is the force caused by crustal plate movement, is susceptible to regional geological structure and generally has an irregular distribution. According to the results of in situ stress measurements, the horizontal stress is higher than the gravity stress of the shallow strata (the depth is within $1200 \mathrm{~m}$ ), and the ratio is 1.4-2.3 (Kang et al., 2010). By measuring the in situ stress of the Kailuan mining area, it is found that the tectonic stress of the outburst danger area is larger than that of other low threat areas (Han et al., 2007). The formation and migration of oil and gas are strongly influenced by the evolution of the tectonic stress field (Zeng et al., 2010). Tectonic stress leads to unevenness in coal permeability, where the permeability is low in high-stress zones and high in low-stress zones (Meng et al., 2011). In addition, high tectonic stress zones often cause abnormalities in gas pressure and gas content, and an outburst often occurs in this area. The direction and size of the present tectonic stress field strongly affect the stability of the roadway. The roadway that is parallel to the tectonic stress has the best stability, while the worst stability is vertical to the tectonic stress (Gadde, 2003; Gale, 1991; Singh et al., 2001). The high tectonic stress reduces the strength of the coal, developing a large area of tectonic coal.

Through measurements of the ground stress, many researchers have studied the effect of geostress on CAGO. In fact, the tectonic stress and tectonic stress field play a 
more critical role on the outburst than that of gravity stress, which is a component of the in situ stress. Since the tectonic stress field cannot be measured, there are few studies about the influence of the tectonic stress and tectonic stress field on CAGO. In this paper, the paleo-tectonic stress field evolution and its effect on CAGO are analyzed in the Pingdingshan eastern mining area. Based on the measured geostress data, the size and direction of the modern tectonic stress field are analyzed, and the effect of modern tectonic stress field is studied. The effect of the tectonic stress field on CAGO is researched in terms of the occurrence of gas, tectonic coal and the formation of geological structure.

\section{Materials and Methods}

\section{Regional geological background}

The eastern mining area is located in the eastern part of the Pingdingshan Coalfield, which includes the No.8 mine, No.10 mine, No.12 mine and Shoushan mine. To facilitate the comparative analysis, this paper also includes the No.1 mine into the eastern mining area. The main geologic structure of the mining area is the Likou syncline; the axial direction is roughly $\mathrm{NW}^{\circ} 0^{\circ}$, and the axial surface is nearly upright. The northwest limb is relatively gently dipping, the southeast limb is relatively tight, and the two limbs are basically symmetrical; the stratigraphic inclination of this structure is generally $5-15^{\circ}$. There are many secondary folds that were developed by the two limbs of the Likou syncline, which are mostly NW-oriented, including the Niuzhuang syncline, the Guozhuang anticline, the Baishishan anticline, and the Lingwushan syncline. The fault structure is very developed in the mining area and mainly includes normal faults and strike-slip faults. The fault directions are divided into two groups: one is NW, including the Baishigou fault, the Huoyan fault, the F1 fault, and the Niuzhuang reverse fault; the other is NE, including the Goulifeng normal faults and some small faults (Figs. 1,2,3).

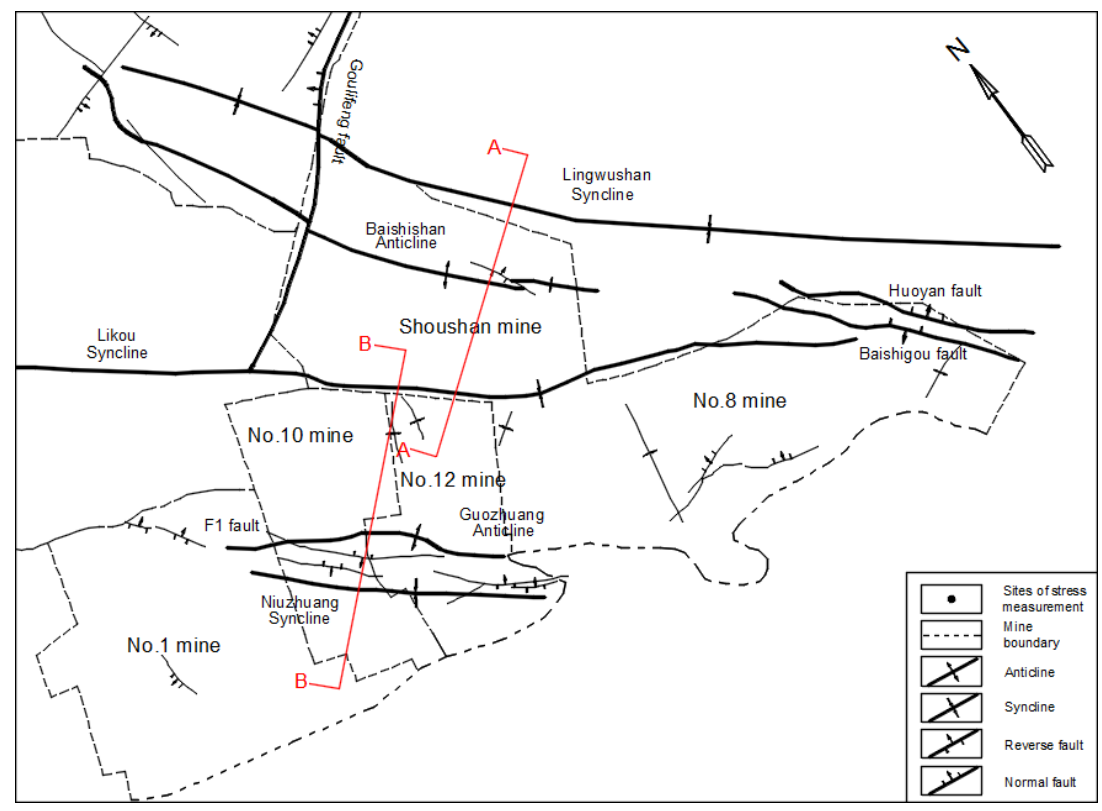

Figure 1. Geological structure outline and geostress measuring point distribution map of the Pingdingshan eastern mining area 


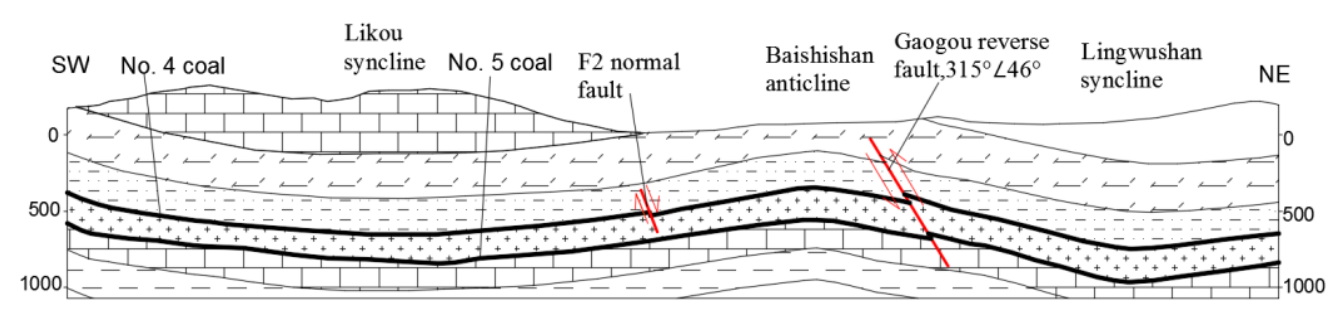

Figure 2. Likou syncline-Baishishan anticline-Lingwushan syncline profile map (A-A)

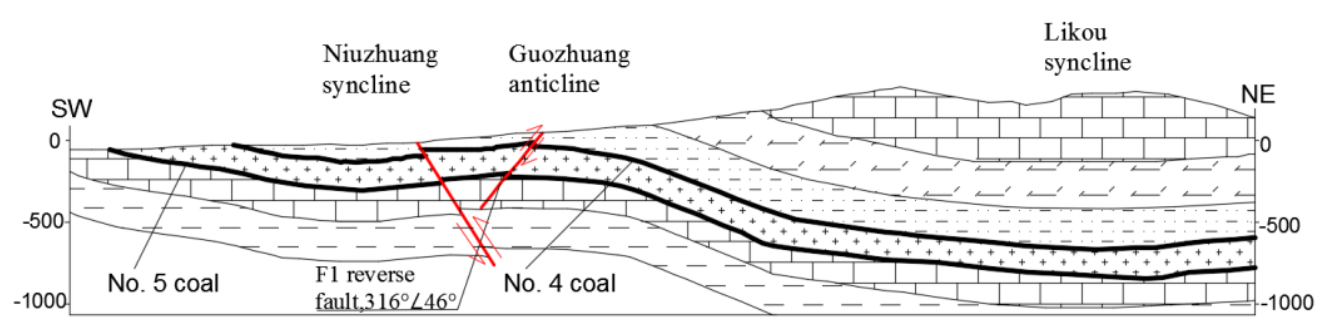

Figure 3. Niuzhuang syncline-Guozhuang anticline-Likou syncline profile map (B-B)

\section{Characteristics of the tectonic stress field in the Pingdingshan eastern mining area}

The tectonic stress field is divided into the paleotectonic stress field and the modern tectonic stress field according to the period of action. The paleotectonic stress field generally refers to the stress field generated during the tectonic movement before the late Tertiary, while the modern tectonic stress field refers to the stress field generated during the tectonic movement after the Neoid. In this section, the characteristics of the paleotectonic stress field and the modern tectonic stress field in the Pingdingshan eastern mining area are analyzed.

\section{Analysis of tectonic stress field evolution}

The Pingdingshan eastern mining area is located in the south of the North China plate, which has experienced many tectonic movements, such as the Indosinian, Yanshan, Himalayan and new tectonic periods. Different tectonic stress fields lead to the deformation, superposition, erosion and transformation of coal strata, which finally form the geological structure of mining area.

1) In the Indosinian movement period, the collision between the southern margin of the North China plate and the Yangzi plate formed a near SN extrusion tectonic stress field, as shown in Fig. 4(a). The EW squeeze and thrust fold structures are developed in the North China plate, which were mainly a broad and gentle fold caused by stratigraphic uplift. The Indosinian tectonic movement has little effect on the study mining area, and there is no EW geological structure in this area, which illustrates this view well. The tectonic stress field in this period shows the uplift and denudation of the strata in the Pingdingshan eastern mining area, leading to the absence of the Triassic strata, and the buried depth of the coal seams gradually becomes shallower. 


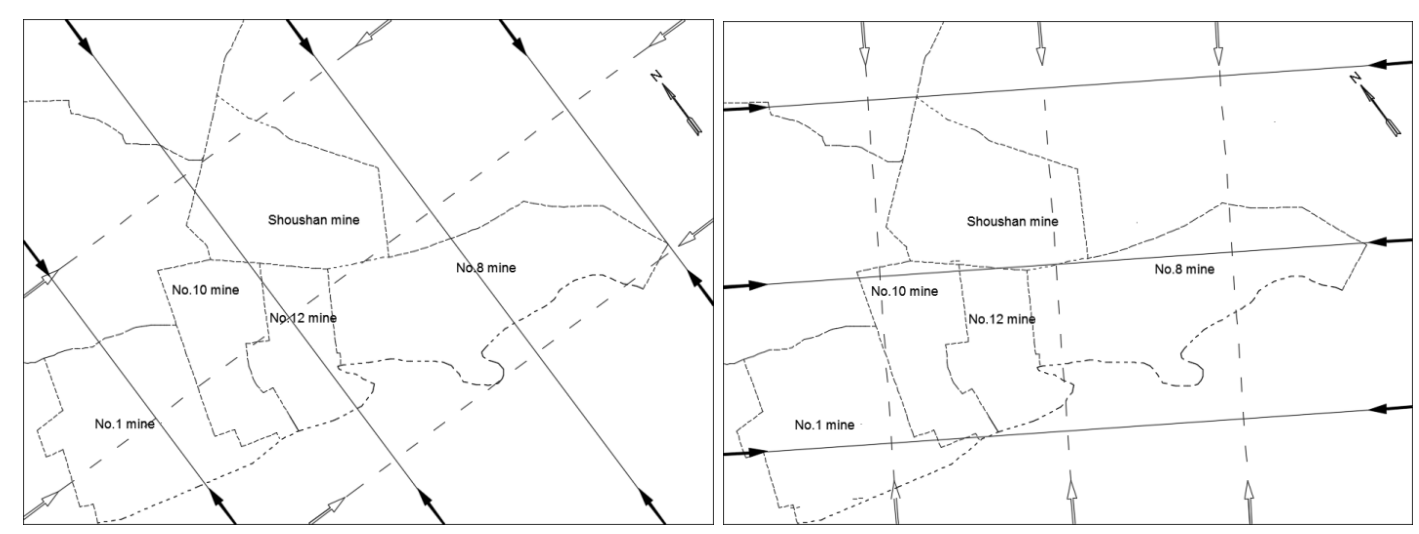

(a) Indosinian tectonic movement

(b) Yanshan early-middle tectonic movement

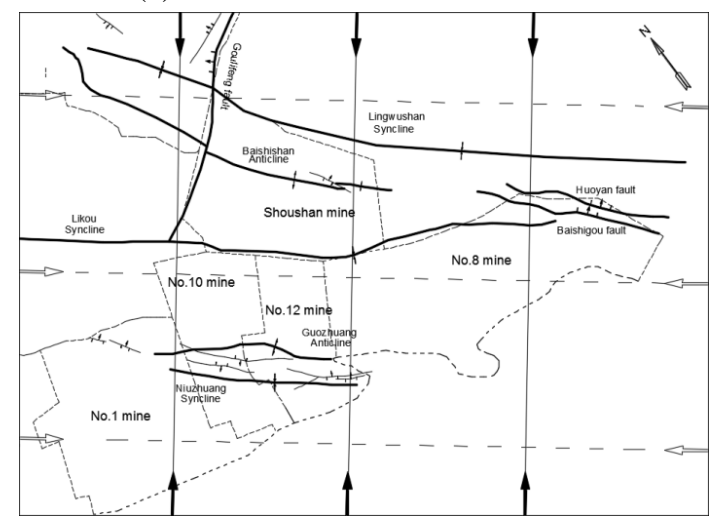

(c) Yanshan Late-Himalayan early tectonic movement

Maximum principal
stress direction Minimum principal
stress direction

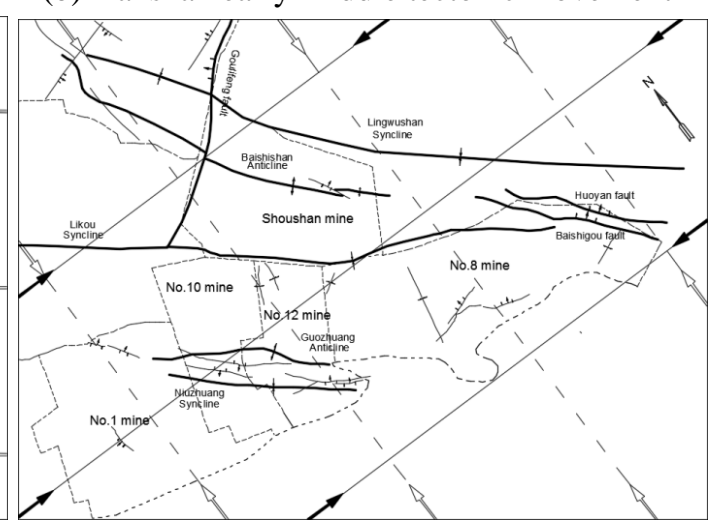

(d) Himalayan Late-modern tectonic movement

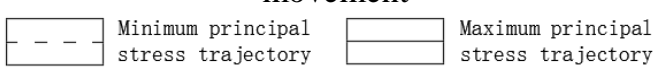

Figure 4. Analysis of tectonic stress field evolution in the Pingdingshan eastern mining area

2) In the Yanshan early-middle tectonic movement period, the north China plate is subjected to a high-intensity NW-SE compressive stress field. A series of NNE-NE thrust faults, fold structures and NW-WNW strike slip faults were formed during this period. The NW trending strike slip faults were mainly formed in the Pingdingshan mining area, but the NNE-NE-trending strong fold and reverse faults were not formed, while the XiangJia fault with NW-WNW trending in the north of the mining area was formed during this period. At this time, volcanic activity was very strong, which led to the increase in geothermal energy of coal and rock. Additionally, the depth of the coal seam continued to increase, and a large amount of gas was produced during this period (Fig. 4b).

3) In the Yanshan Late-Himalayan Early Tectonic Movement period, the North China plate was squeezed by the NNE-SSW trending tectonic stress field. Strong thrusting in the SW direction occurred in the Lushan-Wuyang section of the northern margin of the Qinling orogenic belt. The strong compressive stress at the southwest side causes large-scale tectonic movements in the Pingdingshan mining area. A large scale of geological structure with a NW-WNW orientation was formed during the period in the Pingdingshan mining area, such as the Baishishan anticline, the Lingwushan syncline, the Niuzhuang syncline, the Guozhuang anticline, and the Niuzhuang reverse fault. The main geological structure pattern of the Pingdingshan 
was formed in this tectonic movement. Nevertheless, some reverse faults changed into normal faults in the later stage (Fig. $4 \mathrm{c}$ ).

4) In the Himalayan Late-Modern Tectonic Movement period, this tectonic movement is rather weak in the North China plate, and the direction of the tectonic stress field is E-W trending. The tectonic movement of this period has a weak influence on the Pingdingshan mining area, and new controlled folds and faults were not formed in the research area during this period (Fig. 4d).

\section{Analysis of modern tectonic stress field in the Pingdingshan eastern mining area}

In this paper, the in situ stress data of the eastern Pingdingshan mining area are collected to study the modern tectonic stress field (Guo and Ji, 2012; Liu et al., 2009a; Zhang et al., 2009). To ensure the accuracy of the data, all the test data are measured by the hollow inclusion overcoring method (Table 1), and the distribution map of the ground stress measurement points is shown in Fig. 5.

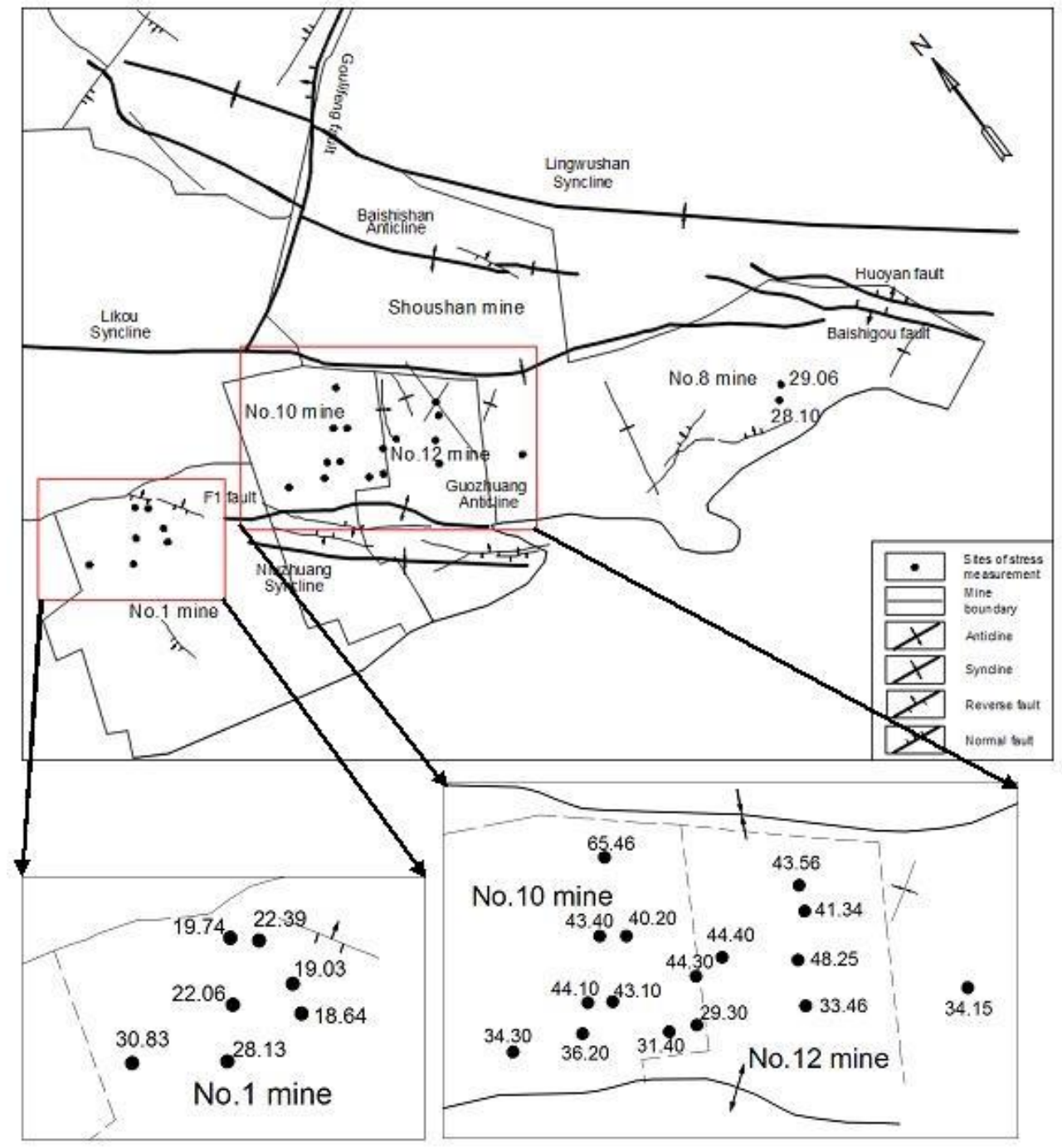

Figure 5. Geostress measuring point distribution map of the Pingdingshan eastern mining area 
Table 1. In situ stress measurement data of the Pingdingshan eastern mining area

\begin{tabular}{|c|c|c|c|c|c|c|c|c|c|c|c|c|c|}
\hline \multirow{2}{*}{$\begin{array}{l}\text { Mine } \\
\text { name }\end{array}$} & \multirow{2}{*}{ No. } & \multirow{2}{*}{$\begin{array}{c}\text { Depth } \\
\text { (m) }\end{array}$} & \multicolumn{3}{|c|}{ Major principal stress } & \multicolumn{3}{|c|}{ Intermediate principal stress } & \multicolumn{3}{|c|}{ Minor principal stress } & \multirow{2}{*}{$\begin{array}{c}\text { Maximum } \\
\text { modern } \\
\text { tectonic } \\
\text { stress } \\
\end{array}$} & \multirow{2}{*}{$\begin{array}{c}\text { Minimum } \\
\text { modern } \\
\text { tectonic } \\
\text { stress } \\
\end{array}$} \\
\hline & & & $\begin{array}{c}\text { Magnitude } \\
\text { (MPa) }\end{array}$ & $\begin{array}{c}\text { Azimuth } \\
\left({ }^{\circ}\right)\end{array}$ & $\begin{array}{c}\text { Dip } \\
\left({ }^{\circ}\right)\end{array}$ & $\begin{array}{c}\text { Magnitude } \\
\text { (MPa) }\end{array}$ & $\begin{array}{c}\text { Azimuth } \\
\left({ }^{\circ}\right)\end{array}$ & $\begin{array}{l}\text { Dip } \\
\left({ }^{\circ}\right)\end{array}$ & $\begin{array}{c}\text { Magnitude } \\
\text { (MPa) }\end{array}$ & $\begin{array}{c}\text { Azimuth } \\
\left({ }^{\circ}\right)\end{array}$ & $\begin{array}{l}\text { Dip } \\
\left({ }^{\circ}\right)\end{array}$ & & \\
\hline \multirow{8}{*}{$\begin{array}{l}\text { No.1 } \\
\text { mine }\end{array}$} & 19 & 440 & 19.03 & 111.2 & 12.2 & 12.66 & 49.4 & -65.3 & 11.40 & $196 . .4$ & -21.1 & 15.51 & 9.14 \\
\hline & 20 & 490 & 18.64 & 180.8 & 1.5 & 15.12 & 88.3 & 60.0 & 14.39 & 91.7 & -29.9 & 14.72 & 11.2 \\
\hline & 21 & 652 & 22.39 & 170.2 & -14.3 & 17.65 & 79.3 & -3.7 & 14.20 & 155.2 & 75.2 & 17.17 & 8.894 \\
\hline & 22 & 692 & 30.83 & 109.6 & 9.7 & 14.68 & 35.1 & -57.3 & 12.85 & 193.7 & -30.8 & 25.29 & 9.144 \\
\hline & 23 & 633 & 22.06 & 120.7 & -1.1 & 17.63 & 31.4 & 36.4 & 14.99 & 209.2 & 53.6 & 16.99 & 9.926 \\
\hline & 24 & 556 & 19.74 & 98.1 & 53.3 & 16.75 & 39.7 & -21.3 & 14.83 & 141.8 & -28.3 & 15.29 & 12.302 \\
\hline & 25 & 555 & 28.13 & 149.7 & -5.9 & 19.06 & -12.7 & -83.8 & 15.26 & 239.9 & -1.9 & 23.69 & 14.62 \\
\hline & 26 & 900 & 31.7 & 32.4 & 37 & 18.7 & 206.8 & -56.6 & 15.98 & 101.5 & 37 & 24.50 & 8.78 \\
\hline \multirow{3}{*}{$\begin{array}{l}\text { No.8 } \\
\text { mine }\end{array}$} & 1 & 495.4 & 28.10 & 119.23 & -0.43 & 12.46 & 28.49 & -59.68 & 5.97 & 209.50 & -30.31 & 24.14 & 8.4968 \\
\hline & 2 & 807.3 & 34.15 & 224.25 & 3.02 & 22.38 & -16.13 & 72.47 & 14.69 & 153.31 & 17.25 & 27.69 & 15.9216 \\
\hline & 3 & 602.9 & 29.06 & 251.71 & 6.54 & 17.90 & 5.03 & 73.84 & 10.22 & 159.98 & 14.71 & 24.24 & 13.0768 \\
\hline \multirow{12}{*}{$\begin{array}{l}\text { No.10 } \\
\text { mine }\end{array}$} & 4 & 1123 & 65.46 & 60.1 & -1 & 38.06 & 209.4 & -78.5 & 31.3 & 149 & 15.3 & 56.48 & 29.076 \\
\hline & 5 & 1061 & 43.06 & 228.1 & 13.3 & 26.1 & 60.5 & 76.2 & 22.4 & 138 & -2.5 & 34.57 & 17.612 \\
\hline & 6 & 1061 & 44.1 & 60.4 & -1.8 & 28.4 & 155.3 & -71.6 & 24.2 & 149 & 17.5 & 35.61 & 19.912 \\
\hline & 7 & 785 & 34.3 & 202.4 & -16.9 & 22.2 & -141 & 71.4 & 18.3 & -67 & -4.8 & 28.02 & 15.92 \\
\hline & 8 & 793 & 36.2 & 60.3 & 15 & 25.1 & 49.3 & -73.6 & 19.1 & -30 & 3.4 & 29.86 & 18.756 \\
\hline & 9 & 869 & 44.4 & 56 & -13.6 & 25.5 & -26.7 & -11.5 & 17.2 & 21.5 & 70.4 & 37.45 & 10.248 \\
\hline & 10 & 869 & 44.3 & 61.5 & -5.6 & 26.1 & -29.7 & -8.8 & 18.5 & 6.1 & 79.4 & 37.35 & 11.548 \\
\hline & 11 & 514 & 31.4 & 53.2 & 6.1 & 17.5 & 131.1 & -72.6 & 15.4 & 146 & 16.1 & 27.29 & 13.388 \\
\hline & 12 & 514 & 29.3 & 229.1 & -6.8 & 18.3 & 137.4 & -16.9 & 17.1 & 160 & 72.2 & 25.19 & 12.988 \\
\hline & 13 & 914 & 40.2 & 43.1 & -7.8 & 28.3 & 132.2 & 2.3 & 14.2 & 27.5 & 81.4 & 32.89 & 6.888 \\
\hline & 14 & 914 & 43.4 & 229.2 & 9.3 & 23.1 & 133 & -4.5 & 16.4 & 42 & 79.1 & 36.09 & 9.088 \\
\hline & 15 & 1090 & 41.34 & 255.04 & -2.63 & 19.28 & -25 & 75.25 & 17.32 & 165.72 & 14.49 & 32.62 & 10.56 \\
\hline \multirow{3}{*}{$\begin{array}{c}\text { No.12 } \\
\text { mine }\end{array}$} & 16 & 830 & 48.25 & 122.89 & -4.10 & 20.98 & 44.34 & 70.13 & 18.84 & 211.45 & 19.41 & 41.61 & 14.34 \\
\hline & 17 & 620 & 33.46 & 110.24 & -5.39 & 16.94 & -21.50 & -81.93 & 11.81 & 200.80 & -5.98 & 28.50 & 11.98 \\
\hline & 18 & 1100 & 43.56 & 246.44 & 16.32 & 25.13 & 310.02 & -57.20 & 20.81 & 165.24 & -27.59 & 34.76 & 16.33 \\
\hline
\end{tabular}




\section{The hollow inclusion overcoring method}

Due to the high accuracy of the test results, the hollow inclusion overcoring method is the most widely used method to measure in situ stress in coal mines. The steps of the hollow core inclusion method are shown in Fig. 6. As cores are free from the effect of in situ stress and experience recovery of elasticity, drill holes undergo corresponding strain and deformation, and the instrument readings will change as well. The orientation and magnitude of the in situ stress are calculated according to the strain of the drill holes and mechanical parameters of the rock (Han et al., 2016). The in situ stress data in this paper are measured by $\mathrm{KX}-81$ hollow inclusion triaxial stress meter. The $\mathrm{KX}-81$ cell is composed of 12 strain gauges that are inserted into the epoxy cylinder. Three group strain rosettes are pasted around the epoxy cylinder at intervals of $120^{\circ}$. There is a compensating gauge on top of the cell. The structure of the KX-81 cell is shown in Fig. 7.

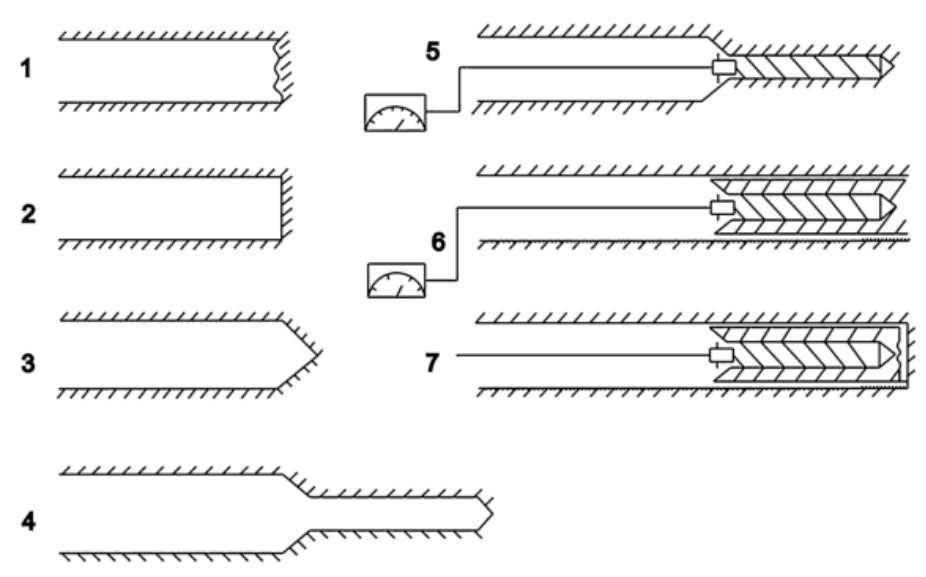

Figure 6. Step of measuring in situ stress with the hollow core inclusion method: (1) a 130-mm main borehole is drilled to design depth of measurement; (2) the bottom of the hole is smoothed; (3) a cone bottom is drilled; (4) a 36- $\mathrm{mm}$ pilot hole is drilled; (5) a hollow inclusion stress cell is cemented into the 36-mm hole at the design depth; (6) the rock is overcored and the strain of the cell is recorded; (7) the core is broken-off (Han et al., 2016)

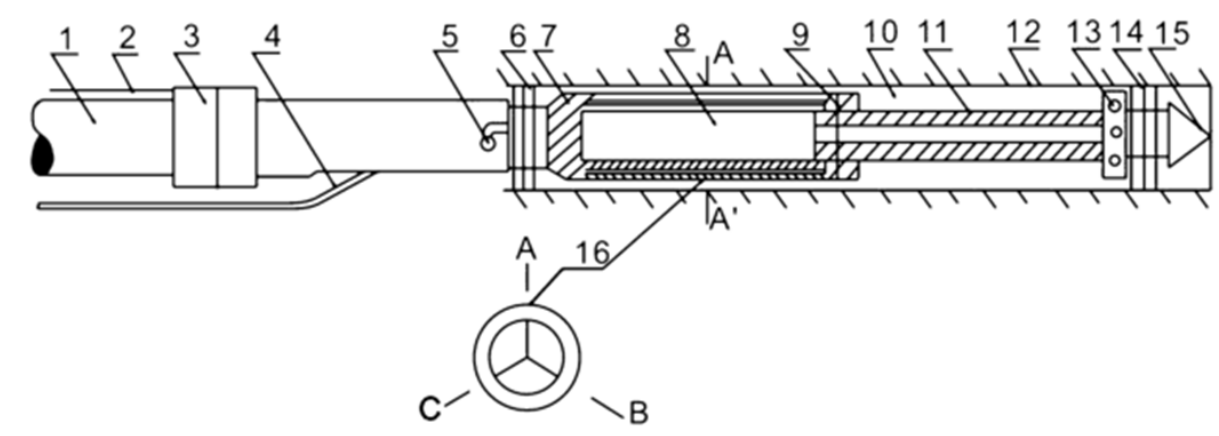

1-mounting stem; 2 -orientator wire; 3 -orientator; 4 -reading wire; 5-directional pin; 6-seal; 7-epoxy resin tube; 8 - cavity (glue filled in it); 9-steady pin; 10 - space between stress meter and hole wall; 11 - plunger; 12-hole drilled in rocks; 13 - glue hole; 14 -seal; 15-guider; 16 - strain rosette.

Figure 7. The structure of KX-81 hollow inclusion triaxial stress meter(Han et al., 2016) 


\section{The direction of modern tectonic stress field}

According to Table 1, a rosette diagram of the maximum horizontal stress direction in the Pingdingshan eastern mining area is drawn (Fig. 8). The direction of the tectonic stress field in the eastern mining area is mainly concentrated in the NEE-WSW direction and the SEE-WNW direction. The direction of 12 measuring points in the 25 measuring points is NEE-WSW, 4 measuring points is SEE-WNW, 3 measuring points is SE-NW. There are 2 measuring points in the direction of SSW-NNE, and the directions of the remaining 4 measuring points are N-S, E-W, SSE-NNW and NE-SW respectively. The direction of tectonic stress in the No.1 mine is mainly SEE and SE, while the stress direction of the No.8, No.10 and No.12 mines is mainly NEE. This change in direction shows that the direction of tectonic stress field in the Pingdingshan mining area varies slightly from east to west, which is possibly due to the influence of the anticline, the Likou syncline, and the Guozhuang anticline. The No.8, No.10 and No.12 mines are all located in the affected area of the Likou syncline and the Guozhuang anticline, while the structure of the No.1 mine is relatively simple and is not affected by the above folds. The formation of the Likou syncline and the Guozhuang syncline caused the torsion of the maximum horizontal principal stress and resulted in changes in the direction of the tectonic stress field, which is believed to confirm the hypothesis that the direction of the tectonic stress field is easily influenced by the geological structure.

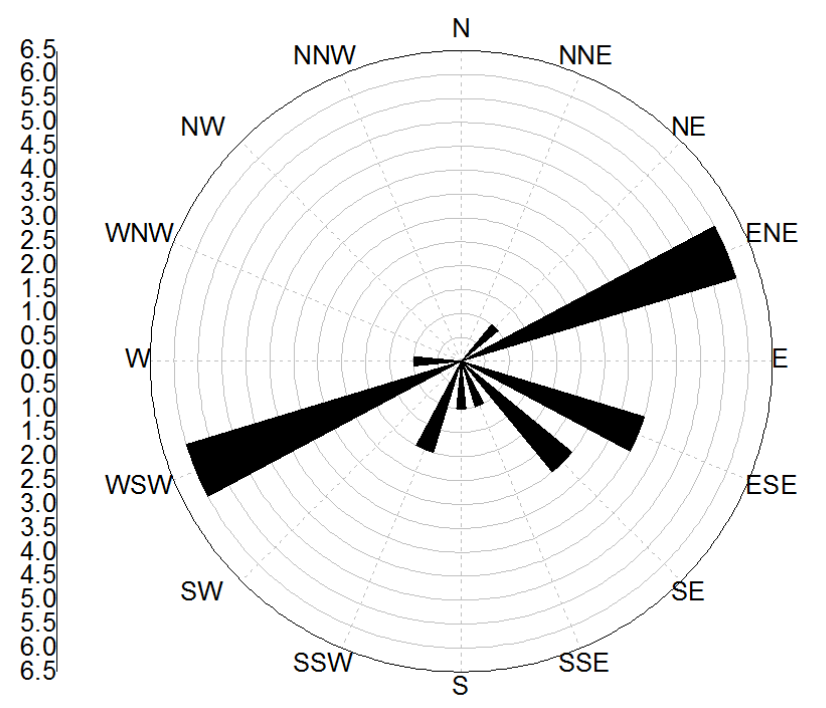

Figure 8. Rosette diagram of the maximum horizontal stress direction

\section{The size of the modern tectonic stress field}

Among the many factors affecting the measured stress, only gravity and tectonic stress can reach a higher order of magnitude; therefore, the measured stress can be regarded as the superposition of gravity and tectonic stress (Khan et al., 2017; Kang et al., 2010). In this paper, it is assumed that the measured stress is mainly reflected by the self-weight and geological tectonism. This paper attempts to analyze the characteristics 
of modern tectonic stress by using the method that the measured geostress value deducts the gravity effect in the Pingdingshan eastern mining area.

The major principal stress is composed of the tectonic stress and the horizontal component of gravity. The horizontal stress $\sigma_{h 1}$ produced by gravity can be expressed as (Zhu and Li, 2001):

$$
\sigma_{h 1}=\frac{v}{1-v} \gamma D
$$

where $v$ represents Poisson's ratio; $\gamma$ represents the bulk density of overlying strata; and $D$ represents the depth of the test point.

In the ideal model of horizontal crustal layering, the maximum horizontal tectonic stress $\sigma_{t H}$, and the minimum horizontal tectonic stress $\sigma_{t h}$ can be expressed as (Qin et al., 1999):

$$
\begin{gathered}
\sigma_{t H}=\sigma_{H}-\frac{v}{1-v} \gamma D \\
\sigma_{t h}=\sigma_{h}-\frac{v}{1-v} \gamma D
\end{gathered}
$$

where $\sigma_{H}$ represents the maximum principal stress and $\sigma_{h}$ represents the minimum principal stress.

The overlying strata of the coal seam in the study area are mostly mudstone and sandstone, thus, this paper assumes $v=0.25$ and $\gamma=24 \mathrm{kN} / \mathrm{m}^{3}$. According to formulas (2) and (3) and the measured principal stress data, the maximum horizontal tectonic stress can be calculated. The overall trend of the maximum horizontal tectonic stress increases with depth (Fig. 9), and the relationship can be approximated by:

$$
\sigma_{t H}=0.034 \mathrm{D}+3.04
$$

According to Table 1, the maximum tectonic stress range is $14.72-56.48 \mathrm{MPa}$, with an average of $28.16 \mathrm{MPa}$. According to the criterion of strength grade: $0 \sim 10 \mathrm{MPa}$ is a low-stress area; 10 18 MPa is a medium stress zone; $18 \sim 30 \mathrm{MPa}$ is a high-stress area; and more than $30 \mathrm{MPa}$ is a super-high-stress area. There are 10 measuring points with ultra-high-stress out of 26 measuring points (38.5\%), and there are 11 measuring points with super-high stress $(42.31 \%)$. Therefore, the tectonic stress in the studied area is dominated by ultra-high stress, while the shallow seam shows a high-stress zone and gradually becomes a ultra-high-stress zone with the increase in buried depth. Furthermore, the difference between the maximum tectonic stress and the minimum tectonic stress is $3.52-27.40 \mathrm{MPa} .76 .93 \%$ of the measuring points had a difference of more than $10 \mathrm{MPa}$, with an average of $18.42 \mathrm{MPa}$. The tectonic stress difference can reflect the instability of coal and rock in the mining area. This difference is quite large, which shows that the coal and rock in the area are unstable and prone to deformation and rupture. Particularly under mining disturbance, coal and gas outburst, rock burst and other underground disasters are prone to occur. The outburst accidents occurred mainly in the No.8 mine, No.10 mine, and No.12 mine (Fig. 10), where the tectonic stress is 
exceedingly high, with an average of 33.02 MPa. Furthermore, the direction of stress in this region is mostly NEE-WSW, which is almost perpendicular to the WNW and NWoriented geological structures, and coal is more prone to instability during excavation in this region. However, the tectonic stress in the No.1 mine, which is adjacent to the No.10 mine, is relatively low, with an average of $19.14 \mathrm{MPa}$, and no outburst accidents have occurred so far. This fact demonstrates well that the magnitude and direction of the modern tectonic stress field both have an important influence on the outburst.

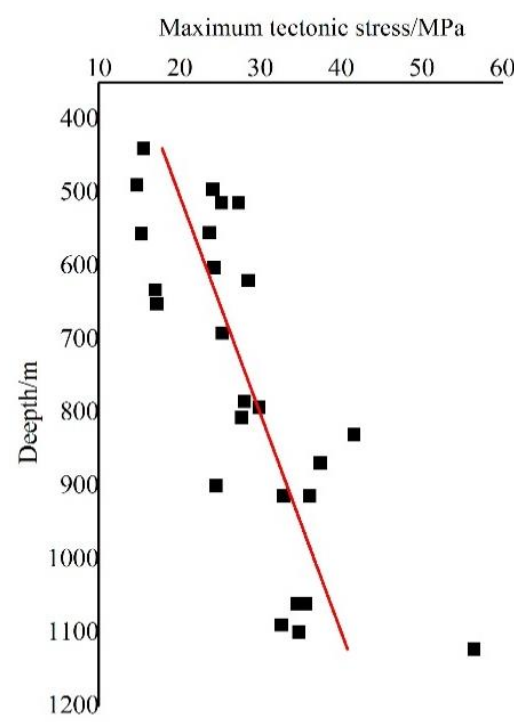

Figure 9. The change in the maximum horizontal tectonic stress with depth

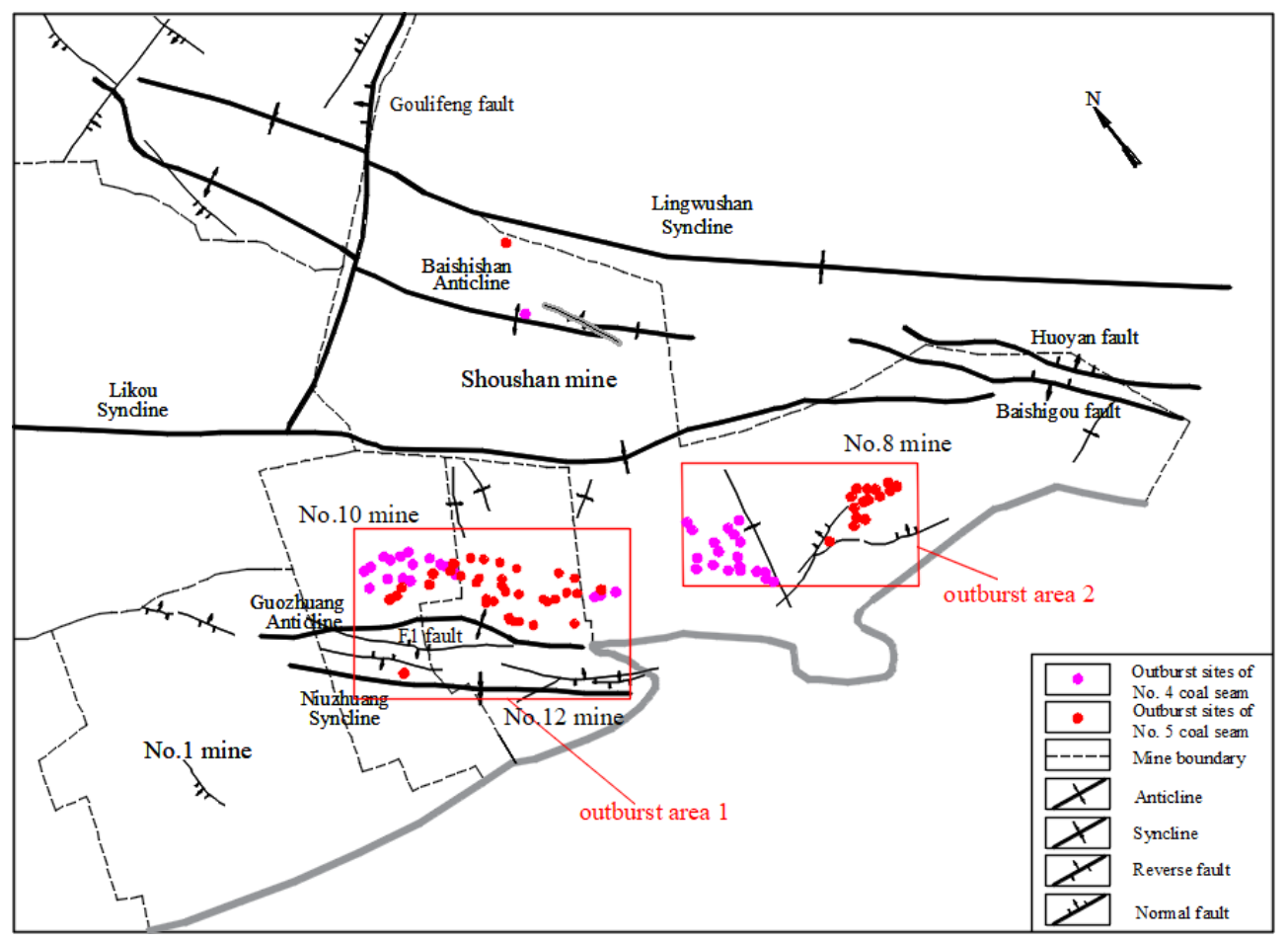

Figure 10. Distribution map of CAGO in the Pingdingshan eastern mining area 


\section{Characteristics of CAGO in the Pingdingshan eastern mining area}

There have been 134 outburst accidents during the mining of the coal seams in the Pingdingshan eastern mining area, with 45 accidents in the No.8 Mine, 51 of them in the No.10 Mine, 36 of them in the No.12 Mine, and 2 of them in the Shoushan Mine. The distribution map of outburst points of No. 4 and No. 5 coal seams is shown in Fig. 10. After a statistical analysis of the 134 CAGO cases, the following common features of outburst can be obtained: (1) Coal and gas outbursts are often accompanied by increased support pressure, outside bulging of the coal wall, jamming of a drilling tool and other stress concentration signs. (2) Most of the outburst accidents occur in the geological tectonic zone, and the effect of small faults on the outburst is particularly obvious. (3) The phenomenon of abnormal gas emission always appears before the occurrences of outburst, which indicates gas pressure and gas content are key factors influencing CAGO. (4) Tectonic coal is widely developed in the outburst accident regions. It can be concluded that stress concentration, gas anomaly, geological structure and tectonic coal are the main factors influencing outbursts in the Pingdingshan eastern mining area. The overlying strata of the research area are the same or similar, and the gravity stress increases linearly with the buried depth (Brown and Hoek, 1978). Owing to the approximation of the gravity stress of the whole mining face, the stress concentration area is mainly caused by the tectonic stress. In addition, the tectonic stress field has a major influence on the geological structure, tectonic coal distribution and gas occurrence and links the above factors. Therefore, combined with the outburst features of the eastern mining area of Pingdingshan, the next section will explore the effect of tectonic stress fields on CAGO from three angles, which are the occurrence of gas, tectonic coal and the formation of geological structure.

\section{Results and Discussion}

\section{Control of the tectonic stress field on CAGO}

\section{Influence of the Tectonic Stress Field on Geological Structure}

The outburst zone is the region that suffered severe structural damage, such as faults, folds, overturning and sliding deformation areas (Farmer and Pooley, 1967). By investigating the outstanding accidents in Australia, Canada, Britain, France and Poland, it is found that more than $90 \%$ of the typical concentrated areas occur in the local strong deformation zone, such as the asymmetric anticline axial, translational faults, nappe faults, strong deformation zones of reverse faults, normal faults, etc. (Shepherd et al., 1981). CAGO almost always occur in areas that are strongly deformed along translational faults, reverse faults, or normal faults (Cao, 2001). A great deal of research by international scholars shows that geological structure is closely related to gas outburst, and the occurrence of outburst is almost directly or indirectly related to geological structure. Therefore, many scholars regard geological structure complexity as one of the indexes to predict CAGO.

As shown in Fig. 10, the outburst accidents mainly occurred in the geological structural belt in the Pingdingshan eastern mining area. The outburst area 1 is mainly affected by the Guo Zhuang anticline, the Niu Zhuang syncline and the F1 fault, while the outburst area 2 is mainly affected by the Jiaozan syncline, the Xindian fault and the Zhangwan fault. The geological structure pattern of the mining area was formed by the evolution of tectonic stress field; therefore, it is important to analyze the control of the 
tectonic stress field on the formation of geological structure to study its impact on the outburst. The late Yanshan-early Himalaya tectonic stress field has the greatest influence on the geological structure of the Pingdingshan mining area. During this period, the Guo Zhuang anticline, the Li Kou syncline, the Niu Zhuang syncline, the Niu Zhuang reverse fault, the F1 reverse fault and the Zhangwan fault were formed by the NNE-SSW compressional stress field (Figs. 11,12). The main geological structure was reformed by the Himalaya tectonic stress field, and the NW-WNW pre-existing faults were transformed from the previous torsional activity to the compressiontorsional activity, while NE-NNE faults were transformed from the torsional activity to the torsional activity. The tectonic deformation caused by the modern tectonic stress field is relatively weak, and no new main geological structure is formed in this period; however, it can affect the development and distribution of the secondary structure in the mining area and the smaller structure in the mine. Additionally, a zone always exists where the modern tectonic stress is abnormally high in the local area, and high stress may lead to fault activation and increase the possibility and risk of CAGO. In general, the tectonic stress field plays a dominant role in the distribution of geological structure.

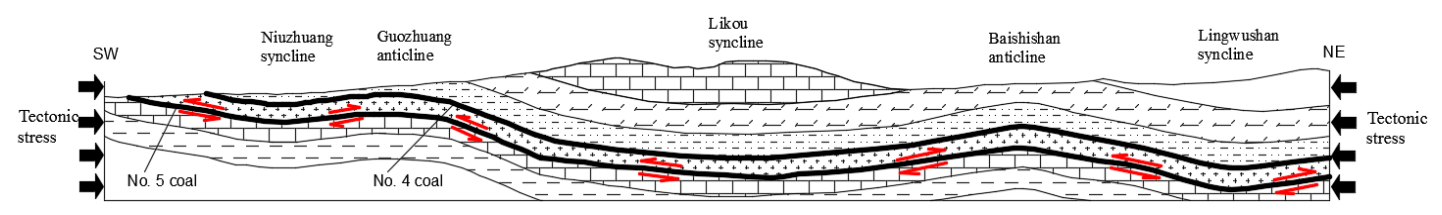

Figure 11. The formation of the partition style folded belt

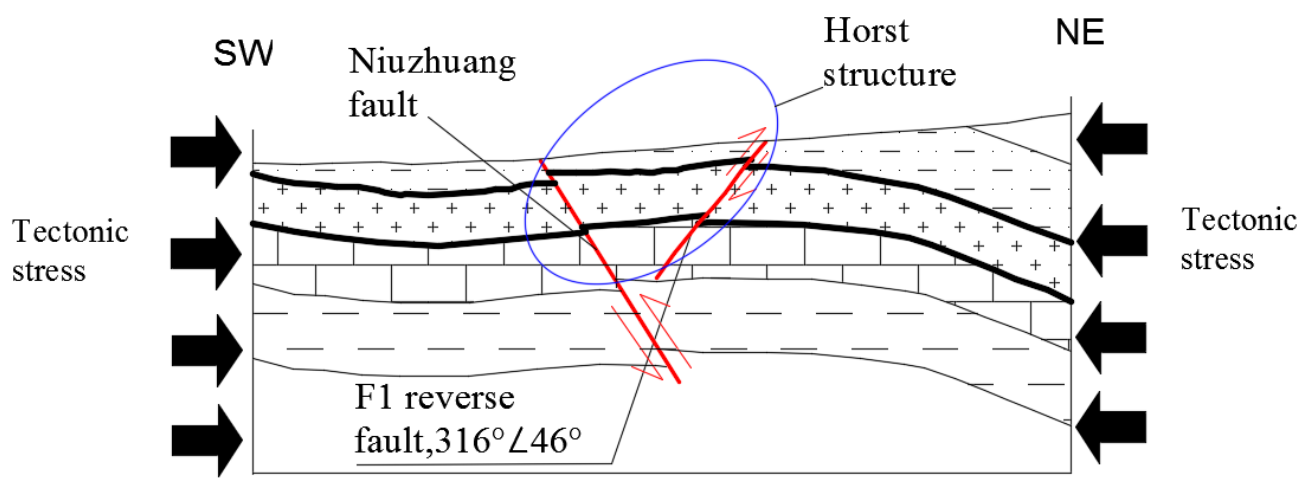

Figure 12. The formation of horst structure

\section{Influence of tectonic stress field on gas occurrence}

The tectonic stress field mainly changes the gas occurrence of the coal reservoir by influencing the permeability of coal seam. The gas flows as a fluid in the fractures and pore structure of the coal seam, and the fractures and porosity structure are squeezed by tectonic stress, resulting in a decrease in coal seam permeability. Therefore, the gas cannot flow normally in the low permeability coal seam. The permeability of the coal seam in the high tectonic stress zone is usually low, and the gas is easily gathered in this zone, resulting in a higher gas pressure and gas content than the surrounding area. 


\section{The control of paleotectonic stress field on permeability}

The permeability of the coal reservoir is affected by various factors, such as geological structure, stress state, fracture characteristics of the coal body and the degree of metamorphism (Cai et al., 2014). The length, diameter, degree of closure and distribution density of the coal body have a great influence on the permeability. During the evolution of coal formation, the tectonic stress field controls the formation and evolution of the sedimentary strata, which affects the thickness and distribution of the coal seam. Due to sedimentation and tectonic stress, a large number of primary fractures are developed in the coal seam. Under the action of later tectonic stress, the endogenetic fracture surface is the weak surface of coal rock, which is prone to rupture and stripping, and some endogenic fractures are transformed into structural fractures in this process. A large number of irregular exogenous fractures are developed in the coal reservoir by the subsequent multi-stage tectonic stress field. The fractured system produced by the multi-stage tectonic stress field controls the regional distribution of permeability of coal reservoirs. The stress concentration often appears in folds and faults zone formed by the paleotectonic stress field, which controls the heterogeneous distribution of coal reservoir permeability. The analysis of the paleotectonic stress field is the basis for studying the regional distribution law of coal and rock structural fractures, and the natural fracture system is a direct factor affecting the permeability. The development of coal seam fractures is controlled by the paleotectonic stress field, and the opening degree of coal seam fractures is controlled by the modern tectonic stress field.

\section{The control of modern stress field on permeability}

The opening degree of the coal reservoir fracture system is controlled by the size and direction of the modern tectonic stress field: the greater the opening is, the greater the permeability. When the activity of modern tectonic stress field exceeds the rupture strength of coal, new structural fractures will be produced. These new exogenous fractures will greatly increase the permeability of coal reservoirs. However, the strong modern tectonic stress field may re-compact the coal after destroying the coal, resulting in a lower permeability of the coal reservoir (Lian and Li, 2005). Furthermore, the modern tectonic stress can provide an important driving force for the seepage of the coalbed methane in fracture system.

We divide fracture space into hard and soft parts along the direction normal to the fracture plane, the hard parts are stress-insensitive portion of the fracture aperture while the soft parts are stress-sensitive portion of the fracture aperture. The averaged fracture aperture under unstressed conditions can be expressed as (Rutqvist et al, 2002):

$$
b=b_{0 r}+b_{0 f}
$$

The averaged fracture aperture under stressed conditions can be expressed as:

$$
b=b_{r}+b_{f}
$$

where subscript 0 refers to unstressed conditions, $b_{r}$ is the residual fracture aperture, which is stress-insensitive portion of the fracture aperture, $b_{f}$ is the stress-sensitive portion of the fracture aperture. 
In the case where the fracture is subjected to an effective stress of $\sigma_{f}$, Hooke's law for the hard and soft parts can be respectively expressed by (Liu et al., 2009b):

$$
\begin{aligned}
& d \sigma_{f}=-k_{F r} \frac{d b_{r}}{b_{0 r}} \\
& d \sigma_{f}=-k_{F f} \frac{d b_{f}}{b_{f}}
\end{aligned}
$$

where subscript $\mathrm{F}$ refers to fracture, $k$ is elastic coefficient of coal body, $\sigma_{f}$ is the effective stress acting on the fracture.

Combining Equations (5)-(8) gives

$$
d b=d b_{r}+d b_{f}=-b_{0 r} \frac{d \sigma_{f}}{k_{F r}}-b_{f} \frac{d \sigma_{f}}{k_{F f}}
$$

The following equation can be obtained by integrating Equations (7)-(8) (Liu et al., 2009b):

$$
\begin{gathered}
b_{r}=b_{0 r}\left(1-\frac{\sigma_{f}}{k_{F r}}\right) \\
b_{f}=b_{0 f} \exp \left(-\frac{\sigma_{f}}{k_{F f}}\right) \\
b=b_{0 r}\left(1-\frac{\sigma_{f}}{k_{F r}}\right)+b_{0 f} \exp \left(-\frac{\sigma_{f}}{k_{F f}}\right)
\end{gathered}
$$

Through a large number of experimental data verification, the following equation holds in practice (Goodman, 1976; Barton et al., 1985; Liu et al., 2009b):

$$
1-\frac{\sigma_{f}}{k_{F r}} \approx 1
$$

In this case, Equation (12) can be reduced to:

$$
b=b_{0 r}+b_{0 f} \exp \left(-\frac{\sigma_{f}}{k_{F f}}\right)
$$

Here, $\frac{1}{k_{F f}}=\mathrm{C}_{f}$ (Liu et al., 2009b), $C_{f}$ is the fracture compressibility, Equation (14) can be reduced to:

$$
b=b_{0 r}+b_{0 f} \exp \left(-C_{f} \sigma_{f}\right)
$$


The permeability of coal fracture can be expressed by the following formula (Louis, 1969):

$$
K=c \beta \frac{\lambda b^{3}}{12 \mu s}
$$

where $K$ is the permeability in fracture; $b$ is the average aperture of fracture; $\lambda$ is the unit weight of the fluid; $\mu$ is the dynamic viscosity of the fluid; $s$ is the average spacing of the cleats; $c$ is a constant related to surface roughness of the cleats; $b$ is a constant describing to the connectivity of cleats.

On the basis of the Equation (15) and Equation (16), the permeability ratio of the two different stress levels can be expressed as follows (Liu and Rutqvist, 2010):

$$
\frac{K}{K_{0}}=\left[\frac{\eta+e^{-C_{f} \sigma}}{\eta+e^{-C_{f} \sigma_{0}}}\right]^{3}
$$

where $K$ is the coal permeability of the stress $\sigma, K_{0}$ is the coal permeability of the stress $\sigma_{0}$, and the parameter $\eta=b_{0 r} / b_{0 f}$. Due to the low strength of the coal body, the proportion of fractures that are not sensitive to stress is negligibly small, and Equation (17) can be simplified as:

$$
\frac{K}{K_{0}}=\exp \left[-3 C_{f}\left(\sigma-\sigma_{0}\right)\right]
$$

According to Table 1, the modern tectonic stress of the research area is quite different (Fig. 10). The average value of maximum tectonic stress in serious outburst zone 1 is $34.55 \mathrm{MPa}$, while the average value in No.1 mine is only $18.38 \mathrm{MPa}$, where there has been no CAGO accidents so far. Some work on coal reservoir permeability model indicates that the value of $C_{f}$ ranges from 0.09 to 0.43 (Liu and Rutqvist, 2010; Meng et al., 2011). According to Formula (18), $K / K_{0}$ increases exponentially with the increase in $C_{f}$ if $\sigma$ is less than $\sigma_{0}$; here, we take the minimum value, $C_{f}=0.09$. It can be concluded that the horizontal permeability of the coal seam in the No.1 mine is approximately 80 times of the outburst zone 1 . However, in contrast to $C_{f}=0.43$, $K / K_{0}$ can reach 7000 , which indicates that the permeability of the non-outburst coal seam is much greater than the outburst coal seam. The modern tectonic stress in the study area is 18.64-65.46 MPa and does not exceed the rupture strength of coal rock; therefore, the regional tectonic stress field mainly controls the permeability by controlling the deformation degree of coal reservoir fractures. The low permeability coal seam leads to ultra-high gas content and gas pressures in outburst zone 1, where the original gas content and gas pressure in this area is respectively above $20 \mathrm{~m}^{3} / \mathrm{t}$ and 1.8 $\mathrm{MPa}$, which is far greater than the outburst critical value of $6 \mathrm{~m}^{3} / \mathrm{t}$ and $0.6 \mathrm{MPa}$. Nevertheless, the tectonic stress in the No.1 mine is approximately $20 \mathrm{MPa}$, and the original gas content and gas pressure are only approximately $5 \mathrm{~m}^{3} / \mathrm{t}$ and $0.5 \mathrm{MPa}$, respectively. It is well illustrated that modern tectonic stress leads to low permeability of coal reservoirs, high gas content and high gas pressure. 


\section{Effect of tectonic stress field on tectonic coal}

The strength of tectonic coal is much lower than that of primary structural coal and coal measure strata. While tectonic coal serves as a weak structure in coal measure strata, tectonic coal is more prone to shear instability under the same stress, and outburst accidents are more likely to occur in tectonic coal development areas (Khan et al., 2015; Li et al., 2012). Therefore, the dynamic origin of tectonic coal is the research hotspot, and tectonic stress is the key force to forming structural coal. Coal measure strata are continuously uplifted, extruded and eroded by the paleotectonic stress field, and these geological movements determine the distribution of tectonic coal. The buckle folds are developed in coal measure strata by the compressive action of the tectonic stress, and the Guozhuang anticline and the Likou syncline are buckle folds developed under this mechanism (Fig. 11). Due to the continuous compressive tectonic stress, the strata of fold limbs undergo shear movement, and bedding shear preferentially occurs in coal seams with the lowest strength stratum, eventually developing coal seam faults. The effect of the bedding shear further damages the coal seam structure, forming a certain thickness and layered distribution of tectonic coal, and the thickness and distribution of tectonic coal reflect the scale of the coal seam faults. A vast area of tectonic coal developed in the No.5 coal seam, while an entire layer of tectonic coal developed in the No.4 coal seam. Moreover, the tectonic coal seam is between two layers of primary structure coal, and there are obvious mirror structures in these regions, which is a symbol of the development of the coal seam faults. The later tectonic stress field continues to crush, shear and erode the coal seam, increasing both the thickness of tectonic coal and the degree of coal damage. Fragmented coal and granulated coal gradually transformed into mylonitized coal, and the bedding of mylonitized coal is more disordered, which is a sign that the coal seam experiences a multi-stage tectonic stress field. The coal seam faults are both formed, and tectonic coal is extensively developed in the two limbs of the Guozhuang anticline. The north limb is a serious outburst zone where the thickness of tectonic coal ranges from 1.5 to $2 \mathrm{~m}$. As the coal seam of the southern limb is simultaneously extruded by the Niuzhuang reverse fault, the thickness of tectonic coal in this region increased, with the thickest section reaching $2.3 \mathrm{~m}$. However, due to the shallow depth of the coal seam in the south limb, the gas pressure is relatively small, and outburst risk is lower than that in the north limb.

\section{Study on control mechanism of tectonic stress field to CAGO}

Coal and gas outbursts mainly occur in the complex geological structure area, and the geological structures of the Pingdingshan coal field were formed by the comprehensive tectonic stress field of Indosinian, Yanshan and Himalayan period. Moreover, the uplift, rubbing and shearing of the paleotectonic stress field to the coal strata are the main controlling factors of tectonic coal development. Due to the existence of geological structure, the modern tectonic stress field is always distributed abnormally in the tectonic area, particularly in compressional fault and fold axis, which are prone to stress concentration. The permeability of the coal in these areas is poor, and the gas pressure is usually high when the gas sealing condition is good. Under the combined action of high gas pressure and high tectonic stress, the risk of CAGO is greatly increased. In this section, the outburst area in the Xindian fault of the No.8 mine is taken as the typical case to describe the control of tectonic stress field on CAGO. 
The 13170 belt transport roadway is located in the pinch-out side of the Xindian fault, and small faults are extensively developed in the surrounding area. 8 outburst accidents had occurred during the mining process in this area (Fig. 13).

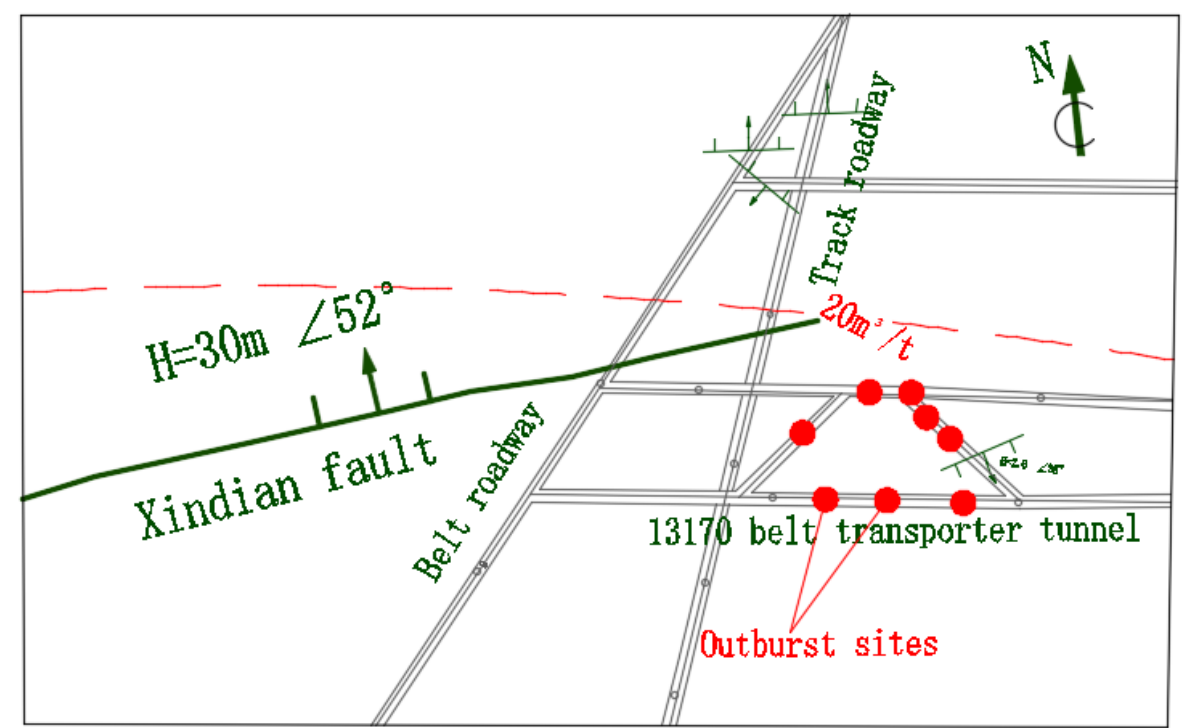

Figure 13. The distribution pattern of outburst accident in Xindian fault area

The Xindian fault is a compresso-shear normal fault with a NNE strike and $30 \mathrm{~m}$ fault throw and was formed under the action of the tectonic stress field in the Yanshan period. The coal measure strata are controlled by the NNE-SSW compressional tectonic stress field in the later stage of the Yanshan movement, and the strong pushing stress of the south-west side causes the formation to be shortened in the NNE direction and extended in the WSW direction, resulting in a series of normal faults with the NNE strike, which include the Xindian fault. The NNW trending compressive stress of the subsequent tectonic movement caused the Xindian fault to be transformed into a compresso-shear structure. The coal seam was uplifted in the Indosinian period and squeezed during the Yanshan late periods, and the coal body was strongly damaged. Additionally, the strong shear effect of late Yanshan caused mylonitization in the No.5 coal seam; thus, mylonite coal is widely developed in this zone, and the Protodyakonov coefficient of coal is only 0.24 . The tectonic stress field of the Himalayan period and the modern period had transformed the Xindian fault into a compressional fault, which is good for gas sealing and preserving. Therefore, the gas pressure and content are $2 \mathrm{MPa}$ and $20 \mathrm{~m}^{3} / \mathrm{t}$, respectively. According to the coal mine safety regulations, these values are far more than the outburst critical values of $0.62 \mathrm{MPa}$ and $6 \mathrm{~m}^{3} / \mathrm{t}$. Based on the in situ stress test data, the maximum horizontal stress in this region is $30 \mathrm{MPa}$, which is an ultra-high stress. When excavating the coal seam in this area, the excavation work undermines the original stress balance, the stress of the coal body in the excavation space is transferred to the surrounding coal and rock mass, resulting in the tectonic stress concentration in the exposed surface of the working face. Due to the low strength of regional coal body, when the stress exceeds the coal bearing limit, the coal body begins to rupture, and the high pressure gas pushes the broken coal to the excavation space at the same time, which is a precursor to outburst. Under the action of modern 
tectonic stress, gravity stress and gas pressure, coal is continuously stripped and thrown out, accompanied by a large amount of gas emission. When the internal coal is insufficient to gather enough high gas pressure to throw out the broken coal rock again, the outburst terminates, and the outburst hole is eventually formatted (Fig. 14).

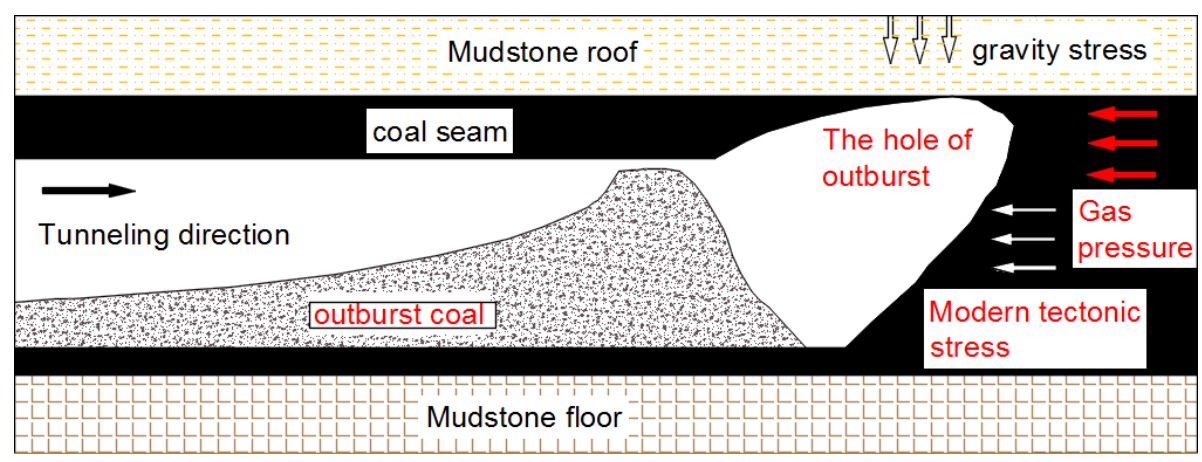

Figure 14. Schematic diagram of outburst formation mechanism in working face

\section{Conclusion}

According to the comprehensive hypothesis and the prominent features of the Pingdingshan mining area, geological structure, gas occurrence, in situ stress, and tectonic coal are the key factors influencing the CAGO. Additionally, the tectonic stress field is the link to these key factors and has a controlling effect on these factors. The evolution of the paleotectonic stress field resulted in the formation of faults, folds and other structures in the Pingdingshan eastern mining area, and the total amount of gas generation was controlled by the paleotectonic stress field. The tectonic stress field drives the gas flowing from the high-stress region to the low-stress area, which determines the gas occurrence characteristics. Moreover, the uplift, squeezing and denudation of the tectonic stress field are the main reasons for tectonic coal development. The modern tectonic stress field has a great influence on the permeability of coal reservoir, and it is easy to form a high gas pressure gradient around the tectonic stress concentration area. Furthermore, the tectonic stress provides energy for the outburst launching and directly participates in the outburst process, greatly increasing the risk and the possibility of outburst.

Acknowledgements. This work was supported by the Key Program of National Natural Science Foundation of China (No.41430640).

\section{REFERENCES}

[1] Aguado, M. B. D., Nicieza, C. G. (2007): Control and prevention of gas outbursts in coal mines, Riosa-Olloniego coalfield, Spain. - International Journal of Coal Geology 69: 253-266.

[2] Beamish, B. B., Crosdale, P. J. (1998): Instantaneous outbursts in underground coal mines: An overview and association with coal type. - International Journal of Coal Geology 35(1-4): 27-55.

[3] Barton, N. R., Bandis, S. C., Bakhtar K. (1985): Strength, deformation, and conductivity coupling of rock joint deformation. - Int J Rock Mech Min Sci 22(3): 121-140. 
[4] Brown, E. T., Hoek, E. (1978): Trends in relationships between measured in situ stresses and depth. - International Journal of Rock Mechanics \& Mining Sciences \& Geomechanics Abstracts 15(4): 211-215.

[5] Cai, Y. D., Pan, Z. J., Liu, D. M., Zhou, Y. (2014): Effects of pressure and temperature on gas diffusion and flow for primary and enhanced coalbed methane recovery. - Energy Exploration \& Exploitation 32: 601-619.

[6] Cao, Y. X., He, D. D., Glick, D. C. (2001): Coal and gas outbursts in footwalls of reverse faults. - International Journal of Coal Geology 48(1-2): 47-63.

[7] Diamond, W. P., Schatzel, S. J. (1998): Measuring the gas content of coal: a review. International Journal of Coal Geology 35(1-4): 311-331.

[8] Ding, J. M., Liang, G. P. (1985): Stress measurement by hydraulic fracturing in oil-well of Norte China. - Acta Seismologica Sinica 7(4): 363-373.

[9] Farmer, I. W., Pooley, F. D. (1967): A hypothesis to explain the occurrence of outbursts in coal, based on a study of west wales outburst coal. - International Journal of Rock Mechanics \& Mining Sciences \& Geomechanics Abstracts 4(2): 189-193.

[10] Gadde, M., Peng, S. (2003): Effect of in situ Stresses on the Stability of Coal Mine Development Workings. - West Virginia University.

[11] Gale, W. J. (1991): Strata control utilising rock reinforcement techniques and stress control methods, in Australian coal mines. - Mining Engineer 150(352): 247-253.

[12] Goodman, R. E. (1976): Methods of geological engineering in discontinuous rocks. West Publishing, New York.

[13] Guo, Q. F, Ji, D. (2012): Study on Measuring and Test Technology of Ground Stress Field in No. 10 Mine of Pingdingshan Coal Mining Group. - Coal Science and Technology 40(4): 12-14. (in Chinese).

[14] Han, J., Zhang, H. W., Zhu, Z. M., Song, J. C. (2007): Controlling of tectonic stress field volution for coal and gas outburst in Fuxin basin. - Journal of China Coal Society 32(9): 934-938. (in Chinese).

[15] Han, J., Zhang, H. W., Liang, B., Rong, H., Lan, T. W., Liu, Y. Z., Ren, T. (2016): Influence of Large Syncline on In Situ Stress Field: A Case Study of the Kaiping Coalfield. - Rock Mechanics \& Rock Engineering 49(11): 1-18.

[16] He, X. Q., Chen, W. X., Nie, B. S., Zhang, M. (2010): Classification technique for danger classes of coal and gas outburst in deep coal mines. - Safety Science 48(2): 173-178.

[17] Kang, H., Zhang, X., Si, L., Wu, Y., Gao, F. (2010): In situ stress measurements and stress distribution characteristics in underground coal mines in China. - Engineering Geology 116(3-4): 333-345.

[18] Khan, A. M., Bakar, N. K. A., Bakar, A. B. A., Ashraf, M. A. (2017): Chemical speciation and bioavailability of rare earth elements in the ecosystem: a review. Environmental Science and Pollution Research 24(29): 22764-22789.

[19] Khan, A. M., Ahmad, C. S., Farooq, U., Mahmood, K., Sarfraz, M., Balkhair, K. S., Ashraf, M. A. (2015): Removal of metallic elements from industrial waste water through biomass and clay. - Frontiers in Life Science 8(3): 223-230.

[20] Lama, R. D., Bodziony, J. (1998): Management of outburst in underground coal mines. International Journal of Coal Geology 35(97): 83-115.

[21] Lian, C. B., Li, H. L. (2005): Mechanism research about effect of in situ stress on coalbed permeability. - Coal Geology \& Exploration 33(2): 30-32. (in Chinese).

[22] Li, S., Tang, D., Xu, H., Yang, Z. (2012): The differences of physical properties of coal reservoirs and their origin mechanism between Zhijin and Panxian Areas, Western Guizhou, China. - Energy Exploration \& Exploitation 30: 661-676.

[23] Liu, H. B., Liu, Y. L., Ren, F. H. (2009a): Distribution regularities of in situ stresses for eighth Mine of Pingdingshan coal mining cooperation. - Journal of Xi An University of Science and Technology 2009(2): 144-148. (in Chinese).

[24] Liu, H. H., Rutqvist, J. (2010): A new coal-permeability model: internal swelling stress and fracture-matrix interaction. - Transp Porous Media 82: 157-171. 
[25] Liu, H. H., Rutqvist, J., Berryman, J. G. (2009b): On the relationship between stress and elastic strain for porous and fractured rock. - International Journal of Rock Mechanics \& Mining Sciences 46(2): 289-296.

[26] Louis, C. (1969): A study of groundwater flow in jointed rock and its influence of the stability of rock masses. - Rock Mech Res Rep 10. Imperial College, London.

[27] Martin, C. D., Chandler, N. A. (1993): Stress heterogeneity and geological structures. Int J Rock Mech Min Sci Geomech Abstr 30(7): 993-999.

[28] Meng, Z. P., Zhang, J. C., Rui, W. (2011): In situ stress, pore pressure and stressdependent permeability in the Southern Qinshui Basin. - International Journal of Rock Mechanics \& Mining Sciences 48(1): 122-131.

[29] Qin, Y., Zhang, D. M., Fu, X. H., Lin, D. Y., Ye, J. P., Xu, Z. B. (1999): A discussion on correlation of modern tectonic stress field to physical properties of coal reservoirs in Central and Southern Qinshui Basin. - Geological Review 45(6): 576-583.

[30] Rutqvist, J., Wu, Y.-S., Tsang, C.-F., Bodvarsson, G. (2002): A modeling approach for analysis of coupled multiphase fluid flow, heat transfer, and deformation in fractured porous rock. - International Journal of Rock Mechanics \& Mining Sciences 39: 429-442.

[31] Sbar, M. L., Engelder, T., Plumb, R., Marshak, S. (1979): Stress pattern near the San Andreas Fault, Palmdale, California from near surface in situ measurements. - Journal of Geophysical Research Solid Earth 84(B1): 156-164.

[32] Shepherd, J., Rixon, L. K., Griffiths, L. (1981): Outbursts and geological structures in coal mines: A review. - International Journal of Rock Mechanics \& Mining Sciences \& Geomechanics Abstracts 18(4): 267-283.

[33] Singh, R. N., Porter, I., Hematian, J. (2001): Finite element analysis of three-way roadway junctions in longwall mining. - International Journal of Coal Geology 45(2-3): $115-125$.

[34] Torano, J., Torno, S., Alvarez, E., Riesgo, P. (2012): Application outburst risk indices in the underground coal mines by sublevel caving. - International Journal of Rock Mechanics \& Mining Sciences 50(1): 94-101.

[35] Zeng, L. B., Wang, H. J., Gong, L., Liu, B. (2010): Impacts of the tectonic stress field on natural gas migration and accumulation: A case study of the Kuqa Depression in the Tarim Basin, China. - Marine and Petroleum Geology 27(7): 1616-1627.

[36] Zhang, Y. X., Cai, M. F., Wang, K. Z. (2009): Study on distribution characteristic of in situ stresses for Pingdingshan No.1 mine. - Chinese Journal of Rock Mechanics and Engineering 23(23): 4033-4037. (in Chinese).

[37] Zhang, R. L., Lowndes, I. S. (2010): The application of a coupled artificial neural network and fault tree analysis model to predict coal and gas outbursts. - International Journal of Coal Geology 84(2): 141-152.

[38] Zhu, H. C., Li, H. (2001): On tectonic stress in rock mass. - Shui Li Xue Bao 32(9): 8185 . 